\title{
The Challenges of Online English Language Teaching From EFL Instructors' Point of View in KKU, Tehama Campus During COVID 19 Period
}

\author{
Mona M. Hamad \\ English Department, College of Science \& Arts Muhayil, King Khalid University, Saudi Arabia \\ Alrafeea S. Dafaallah \\ English Department, College of Science \& Arts Muhayil, King Khalid University, Saudi Arabia \\ Abdulbasit A. Alhaj \\ English Department, College of Science \& Arts Muhayil, King Khalid University, Saudi Arabia
}

\begin{abstract}
Spreading of COVID 19 in the whole world affected all fields of life in general and education in specific; this study aims at finding out the challenges of online teaching from EFL instructors' point of view at KKU/ Tehama campus during the COVID 19 period in the field of 1- Quality of teaching.2 Students' interaction. 3- Results of Authentic learning outcome. 4- Instructors' planning and correction load 5- Macro and Micro skills. A questionnaire is used to collect the data from instructors who work in Tehama. The researchers used the descriptive-analytical approach. Data were analyzed using SPSS. The finding of this study reflected many challenges of online teaching from Instructors perspectives, such as the difficulty of reflecting desired learning outcomes due to multiple attempts and students cheating, which results in high marks in grading, interaction problems between instructors and students, multi-tasks that are added to instructors burden beside many other challenges that affect EFL teaching.
\end{abstract}

Index Terms - challenges, online, EFL, COVID19

\section{INTRODUCTION}

Online teaching has been an ideal solution to the current situation due to COVID 19 spread worldwide in general and in Saudi Arabia in specific. King Khalid University started using the Blackboard software in 1912, using it as a supportive method to traditional teaching. Later, Blackboard is used to teach blended courses according to instructors and departments agreement and for fully online teaching for courses taught as a university requirement. In March 2020with the spread of COVID 19, King Khalid University changed all courses from traditional classes and blended classes to fully online classes. It was a critical period for both instructors and students, who find themselves obliged to use the Blackboard for online teaching and learning.

In this study, the researchers will focus on teaching challenges from EFL instructors' point of view at KKU, Tehama Campus period. Teaching is an art that each instructor has his/ her preference of using a specific approach that suits his class feature and his / her philosophy; however, using online teaching forced instructors to use certain teaching methods and approaches, as they cannot apply what they are used to in their traditional class.

Instructors of EFL preserved no efforts to help their students overcome all obstacles they may face during online learning. They used other Apps to support communication with their students, such as Emails and WhatsApp, which made instructors, like doctors in emergency units on call all the time, have to respond on the spot to students' inquiries and questions. This is besides the time they spend sitting in front of their computers planning a module to help students understand a course chapter's content. This burden most of the time deprives instructors of some of their private time. Butcher and Hoosen (2012) state, "People use the term online learning in many different ways. Most broadly, it refers to a method of delivering educational information using the internet. This may range from downloadable content (such as iTunes university content, digital textbooks, and video or audio materials)"

They pointed that open learning helps students to overcome barriers to learning with a reasonable chance of success by having open sources, open access, open educational sources, and Massive open online courses (MOOCs)

\section{AIM OF THE STUDY}

The study aims at exploring the challenges of online teaching from EFL instructors' point of view at KKU/ Tehama campus during the COVID 19 period in terms of:

1. Quality of teaching.

2. Students' interaction. 
3. Authentic results of learning outcomes.

4. Instructors' planning and correction load.

5. Macro and Micro skills.

\section{QUESTION OF THE STUDY}

The study attempts to answer the following question:

What are the challenges of online teaching from EFL instructors' point of view at KKU/ Tehama campus during the COVID 19 period in terms of:

1. Quality of teaching.

2. Students' interaction.

3. Authentic results of learning outcomes.

4. Instructors' planning and correction load.

5. Macro and Micro skills.

\section{SignificAnCE OF THE STUdy}

In this study, exploring the challenges of online teaching from EFL instructors' points of view will help find solutions that may help overcome these challenges in both KKU community in specific and Saudi Arabian higher education in general. Results will help EFL instructors in Higher Education preserve the best learning outcomes desired for different EFL courses, whether for micro or macro skill, to maintain the best educational results.

\section{LITERATURE REVIEW}

In this section, the researchers displayed previous studies according to the questionnaire domains to review related studies.

\section{Studies related to the quality of teaching}

An emerging number of individual researchers and research centers contributed to the literature related to the pandemic's challenges on the education world, which inevitably affect the standards of the students. Khang D. Nnguyen, Md. et al., (2013) expressed their fears on the extent to which the current pandemic challenges the next generations' education. On their paper, they stated that some people may ask, "why bother with education" (p. 21), and hence, it seems the novel ways of education have transformed the instructors into new learners. Their stand is supported by Adegboye O. and Quadri A. (2020), Adedoyin B. and Soykan E. (2020), and Abuhammad S. (2020) that personal, social, technical and finical barriers are outstanding factors affecting online learning. Bennett et al., 2008, cited in Adedoyin O. and Soykan E. (2020), points out that "students and instructors with low digital competence are liable to lack behind in online learning." (p.5). Abuhammad S. (2020), reports that some parents are dissatisfied as online learning does not meet the needs of the students. Rebeiro 2020, cited in Adedoyin O. and Soykan E. (2020), adds logistical and attitudinal modifications as challenges facing online learning.

Raines et al. (2011) pointed out that students' cheating and quality of learning are the barriers of online teaching; he showed how students identified breaking the rules, dishonesty, and not doing the work as behaviors emblematic of cheating lead to better grades and success. Also, Dendir. S and R. Stockton Maxwell (2020) showed that cheating in online courses is clear but using proctoring was an effective tool to lessen academic dishonesty in online courses. Ross, J. (2020) discussed different points of view about students cheating and exam invigilation, comparing online exams and class exams, showing no big difference. Golden and Kohlbeck, M. (2020) revealed that using test bank question help to decrease cheating as students find difficult to find answers on the internet, and they pointed the importance of revising old bank questions by making new questions or by paraphrasing questions to reduce the benefits from enormous cheating opportunities.

Butcher and Hoosen (2014) stated, "fundamental judgments about quality should not depend on whether education is provided in a traditional or post-traditional manner" He pointed that quality assurance of distance education should be similar to general education assurance in higher education.

Bunmi S. et al. (2014) indicated in their study entitled, Using Computer-based technology to improve feedback to staff and students on MCQ that students' responses, showed satisfaction of MCQ in terms of time comprehension revision, while teaching staff is satisfied with the efficient provision of automatic feedback about students' learning progress, which leads to quality assurance and support students learning.

@ ONE ONLINE NETWORK OF EDUCATORS pointed that there are five principles for effective online teaching:

1. Teachers should be present within their course to be effective.

2. Teachers should be effective by applying reasonable methods for encouraging students' access and success while recognizing institutional problems.

3. Teachers should respond to students' needs and use data for continuous course development.

4. Teachers should model moral online interaction while helping students with digital literacy, leading them to succeed.

5. Teachers should realize ongoing professional development is the central factor of their success. 
Christine F. et al. (2019) explained that quality indicators depend on teaching effectiveness. Effective online teachers are facilitators, connectors who lead and work with students to gain success indicators such as: success, students' development over time, and students' application of what they have learned in their work. Nauman A. and Munawar M. (2020) Stated that there is a shortcoming in the course's modules, procedures and control and observe irregular attendance and punctuality of the students.

\section{Studies related to students' interaction}

Fageeh and Mekheimer (2013) pointed out that students' attitude towards face-to-face learning is more positive than online interaction and discussions; however, many students found that BB is helpful and motivating to develop their writing skills. Al-Nofaie, H. (2020) revealed that students who learn by online learning lack physical interaction and have many technical problems such as internet speed and lack of headphones and home distractions, making it difficult to replace traditional in-class teaching with fully online teaching. Reese, S. A. (2014) stated that online learning environments in higher education must be a mixture of synchronous and asynchronous learning opportunities. This mixture should facilitate communication and collaboration between classmates and instructors, hence giving them a chance to explore, research, and create. Leontyeva A. Irina (2018) revealed that students like online learning but complain about teachers' quality of interaction during technical problems. This is beside the internal and external factors that hinder online implementation, such as resource control, inappropriate administrative structure, etc. The online learning environment is also one of the critical challenges that affect learning outcomes. Hee K. et al. (2013) investigated the learner-instructor interaction factors that can predict the learner's outcomes in the online learning environment. The study found out that instructional interaction factors have predictive power on learners' perceived learning achievement than social factors. The study also maintains that private learner-instructor communication cannot guarantee learners' facilitated achievement.

\section{Studies related to authentic results of learning comes:}

Authentic learning outcomes can be achieved by student management and engagement, affecting online learning platforms' challenges. According to Everett D. et al. (2015), in the online environment, it is a challenge to engage students with the content, with each other, and with the instructor" (p. 69). Lathifah Z.et al. (2020) investigated the challenges of student management at the time of the pandemic in Indonesia, they found out that many students got stressed when they are given a lot of tasks. Finn and Zimmer (2013), cited in Everett D. (2015), proffers four factors necessary for student engagement: the understanding of engagement behavior, connecting the engagement many to the appropriate students' workplace, improving the academic environment, and remaining engaged as an outcome of being in school.

Arnold S. (2012) noted that "Oftentimes students indicate dissatisfaction when instructors of online courses offer them synchronously at scheduled times due to their time/place-bound circumstances" Also online assessment is the lack of test reliability of a non-proctored online exam is its equivalence to a take-home or open-book test (p. 190)".

Pedersen C., White R. and Smith D. (2012) "Cheating and plagiarism are two frequent and controversial issues that arise in online assessments." (p. 35), and they recommended the adoption of the authentic assessment approach for minimizing academic dishonesty among students.

Studies related to instructors' planning and correction load:

Adedoyin O. and Soykan E. (2020) utterly proclaim the urgent need during the digital transformation for unbiased and evenhanded grading policies to overcome the pandemic-related anxiety that negatively affects students' academic performance, as well as racial, and economic resource differences. He also mentioned the lack of effective training among the larger parts of instructors and their ability to deliver high-quality instruction remotely. He stated that "students with outdated technological devices might find it hard to meet up with some technical requirements of online learning." (p. 4). Xhaferi, B., and Xhaferi, G. (2020) stated that online teaching and learning is a good solution for the COVID19 pandemic, but the traditional classroom elements are lost in using online teaching, and the teachers should consider reducing homework amount that given to the students as they think it was too much. Vadivel, B., Mathuranjali, M., and Khalil, N. R. (2021) pointed that teaching language online in the year 2020 has proved to be a challenging task without the live teacher presence, in spite of using technology, which was a solution for people across the world by using different applications. Devenyi, G. A., et, al (2018) provide ten rules to help teachers who spend countless hours work on planning their lessons; these ten rules work as an alternative. These 10 rules provide an alternative1. Clarify your audience 2. learner profile 3. Teach best practices for lesson development 4. Encourage and empower control; these5. Build a community around lessons 6. Publish periodically and recognize contributions 7. Evaluate lessons at several scales. 8. Reduce, reuse, recycle 9. Link lessons to other resources 10. You can't please everyone. Tomei, L. A. (2006). found that online teaching demanded a minimum of $14 \%$ more time than traditional instruction spent in preparing instructional content, which raises instructors cannot and traditional teaching was more stable than online teaching, Tomei also pointed three teaching components: instructional content, counsel and advisement, and student assessment that are affected by online teaching, they also pointed that the ideal number for s; in Tomei online class are 12 students. Armăsar, I. P. (2020) pointed that besides the advantages that are gained from online language teaching, there are many disadvantages such as: instable internet connection, devices' the crash or platform drawback, potentially disturbing factors, the passivity of the students, the lack of motivation, and real connection between students and teacher, lacking of a sense of belonging to a group or an institution, etc. 


\section{Studies related to Macro and Micro skills:}

The four main language skills or the macro skills, whether if they receptive skills (i.e., listening, speaking) or productive skills (i.e., reading, writing), are regarded as the basis of most English language teaching (ELT) practices around the world. The sub-skills or micro-skills such as grammar, vocabulary, and pronunciation are also emphasized in teaching English to integrate the main four skills.

Narayanan, R., and Mathew, P. (2020) indicated that students were not motivated performed poorly. In contrast, the high achievers were engaged in self-study and were, to some extent, independent learners. Srivastava, R. (2020) stated that virtual education's success depends upon the effective content generation, delivery of its design and planning, use of effective teaching/learning tools that can work as a supplement to the teachers' efforts. Colleges, learners, and educational institutions need to be well-equipped to adapt to online teaching and learning. Martínez, R., and RuizJiménez, M. (2020) show that students are satisfied with the experience of a flipped classroom and with their summative, formative assessment. Students also consider their learning process better with this has been better-flipped classroom. Add to that flipping courses helped to improve students' academic results, compared with traditional lectures. Haidari, M. et, al. (2020) The results of all 17 articles show that using social media and Wikis platforms helped improve learners' writing skills. And recommended utilize them by both teachers and learners teaching and learning. Sherine, A. et, al. (2020) stated that using smartphones resulted in improved language learning engagement. And has a positive effect on the participants' speaking skills fluency. Kiili, C., and Leu, D. J. (2019) pointed three results for their study: 1) a methodology and a taxonomic system were developed for the study of information sources involved in collaborative synthesis; 2) the integration of ideas from multi-participants texts was difficult for adolescent students; 3) students with better essays used more online information whereas students with less remarkable essays relied more on prior knowledge that was activated during online reading. While Syahrin, S., and Salih, A. A. (2020) revealed that students prefer online classrooms reflected by technology and students' preferred learning style. However, results showed that receptive skills (listening and reading) are more focused than productive skills (speaking and writing), requiring more focus by instructors and educationist. Also, Newman, B. (2020) highlighted the drawback of online teaching, including the loss of language inhibitions in students with ESL, the missing body language reflecting students' understanding or disagreement, and the loss of responsive interaction with learners.

\section{RESEARCH MethodOLOGY}

\section{Data Collection}

This study has been carried out at King Khalid University in Tehama campus colleges in the academic year 20202021 using the descriptive-analytical approach.

\section{Population of the Study}

62 EFL instructors teaching at King Khalid University, Tehama Campus, constitute this study's population. 43 instructors out of 62 instructors responded to the questionnaire. When this study was carried, the total number of instructors is 82 instructors in all Tehama. 20 of them were outside KSA for post-graduate studies.

\section{Study Instrument}

An electronic questionnaire is used as an instrument for collecting the data of this study; the questionnaire consists of 38 questions divided into 5 domains: A. Quality of teaching, B. Students' interaction, C. Authentic results of learning comes, D. Instructors' planning and correction load, E. Macro and Micro skills. Responding to each domain's questions may reflect the challenges of online English language teaching from EFL instructors' point of view in KKU, Tehama Campus during the COVID 19 period.

\section{Validity and Reliability of the Questionnaire}

Table .1, which reflects the use of a: Cronbach's Alpha. b: Spearman and Brown. c: One-Sample Tests, it is obvious that $(0.908)$ and $(0.931)$ reflect high validity and reliability of the questionnaire proving its suitability for this study.

TABLE 1.

\begin{tabular}{|l|l|l|}
\hline \multicolumn{2}{|c|}{ VALIDITY AND RELIABILITY OF THE QUESTIONNAIRE } \\
\hline Reliable & Cronbach's Alpha & Spearman and Brown \\
\hline Validity $=\sqrt{\text { Reliable }}$ & 0.824 & 0.867 \\
\hline
\end{tabular}

\section{Data Analysis}

The participants' responses were received through google forms and the results were coded and analyzed using SPSS. The researchers used t-test through t-distribution table to find if the results are significant or not. It is expected that the results reflect the challenges of online English language teaching from EFL instructors' point of view in KKU, Tehama Campus during the COVID 19 period.

The first part of the questionnaire addresses the research and its importance. The second part of the questionnaire is about the instructors' basic information. Tables 2, 3, 4, 5 below reflect information about instructors' age, gender, the period they are teaching in KKU, and their EL -teaching experience before Covid19. 
TABLE 2

AGE

\begin{tabular}{|l|l|l|}
\hline Age & Frequency & Percent \\
\hline 25 and less than 35 & 13 & 30.23 \\
\hline 35 and less than 45 & 16 & 37.21 \\
\hline 45and less than 55 & 10 & 23.26 \\
\hline 55 and less than 65 & 4 & 9.30 \\
\hline Total & 43 & $100 \%$ \\
\hline
\end{tabular}

From the above table, it is obvious that the age of the majority of the participants is between 35 and less than 45 with $37.21 \%$, and the age of the second group of the participants is between 25 and less than 35 with $30.23 \%$, and the 3rd group of participants' ages is between 45 and less than 55 with $23.26 \%$, and the minority of the participants' age is between 55 and less than 65 with 9:30\%. These results show that 90.70\% of the respondents can rely on technology. $90.70 \%$ not in the table.

TABLE 3
GENDER
\begin{tabular}{|l|l|l|}
\hline Gender & Frequency & Percent \\
\hline male & 16 & 37.21 \\
\hline Female & 27 & 62.79 \\
\hline total & 43 & $100 \%$ \\
\hline
\end{tabular}

From the table above, we can see that most of the participants are females, and the minority are males as most of the female instructors are out of KSA for postgraduate studies.

TABLE 4

THE PERIOD OF TEACHING EXPERIENCE IN KKU

\begin{tabular}{|l|l|l|}
\hline Time been teaching in KKU & Frequency & Percent \\
\hline 1-5 years & 16 & 37.21 \\
\hline 6-10 years & 21 & 48.84 \\
\hline 11-15 years & 6 & 13.95 \\
\hline Total & 43 & $100 \%$ \\
\hline
\end{tabular}

Table 4 shows that the majority of the instructors have been teaching in KKU for more than 6 years, so they are trained enough by KKU e-learning deanship on using the Blackboard (BB) platform, as the deanship of E- Leaning offers many training courses every year to KKU instructors to be updated in working with the Blackboard). This is beside Tamkin channel, which uses YouTube to post different skills to improve teachers' technical abilities in using the BB. The table shows that only $37.21 \%$ of the instructors have between 1-5 experience working in KKU.

TABLE 5

EXPERIENCE OF E- TEACHING BEFORE COVID19

\begin{tabular}{|l|l|l|}
\hline I have experienced E- teaching before Covid19 & Frequency & Percent \\
\hline Yes & 26 & 60.47 \\
\hline No & 17 & 39.53 \\
\hline Total & 43 & $100 \%$ \\
\hline
\end{tabular}

Table 5 reflects that most of the instructors experienced E-Teaching before Covid19 with $60.47 \%$, reflecting instructors' experience even before the emergence of Covied 19.

An Independent sample of t-test was applied to identify the instructors' responses in a significant difference using statistical equations: a- Cronbach's Alpha b- Spearman and Brown c- One-Sample Test.

Below are the t-distribution tables for the fifth domain items that are tackled in the questionnaire; each domain item was discussed below the tables. 
TABLE 6

QUALITY OF TEACHING

\begin{tabular}{|l|l|l|l|l|l|l|}
\hline Statement & Std. Deviation & t & Salue & reality of 0.05 & Value \\
\hline $\begin{array}{l}\text { 1-Online teaching does not } \\
\text { achieve the prescribed learning } \\
\text { outcomes. }\end{array}$ & 1.8837 & .98099 & 2.565 & 42 & significant \\
\hline $\begin{array}{l}\text { 2-Cheating on online } \\
\text { examination is inevitable. }\end{array}$ & 2.4884 & .85557 & 7.575 & 42 & No idea \\
\hline $\begin{array}{l}\text { 3-Having more than one } \\
\text { attempt for the exam increases } \\
\text { the students chance of } \\
\text { cheating. }\end{array}$ & 2.7907 & .59993 & 14.108 & 42 & significant \\
\hline $\begin{array}{l}\text { 4- Students repeated excuses } \\
\text { and chances may reflect } \\
\text { unreliable grades and results. }\end{array}$ & 2.8837 & .39093 & 23.211 & 42 & agree \\
\hline $\begin{array}{l}\text { 5-Most of the blackboard } \\
\text { questions are objective. }\end{array}$ & 2.6977 & .70828 & 11.088 & 42 & agree \\
\hline $\begin{array}{l}\text { 6-Objective types of questions } \\
\text { do not assess all learning } \\
\text { outcomes. }\end{array}$ & 2.3023 & .93948 & 5.600 & 42 & significant \\
\hline
\end{tabular}

The results of phrase No. 1 in Table 6 reveal that this phrase is significant as the (t) value is (2.565) with a degree of freedom (42) and a probability value (.014) disagreement. This means that online teaching achieved the prescribed learning outcomes according to instructors' responses with (0.05) of validity.

The results of phrase No. 2 in Table 6 reveal that this phrase is significant as the (t) value is (7.575) with a degree of freedom (42) and a probability value (.000) agreement. This means that cheating on an online examination is inevitable according to instructors' responses with $(0.05)$ of validity.

The results of phrase No. 3 in Table 6 reveal that this phrase is significant as the (t) value is (14.108) with a degree of freedom (42) and a probability value (.000) agreement. It means allowing more than one attempt for the exam increases the students' chance of cheating. According to instructors' responses with (0.05) of validity.

The results of phrase No. 4 in Table 6 reveal that this phrase is significant as the (t) value is (23.211) with a degree of freedom (42) and a probability value (.000) agreement. It means that the Students' repeated excuses and chances may reflect unreliable grades and results according to instructors' responses with (0.05) of validity.

The results of phrase No. 5 in Table 6 reveal that this phrase is significant as the (t) value (11.088) with a degree of freedom (42) and a probability value (.000) agreement. It means that most of the blackboard questions are objective according to instructors' responses with (0.05) of validity.

The results of phrase No. 6 in Table 6 reveal that this phrase is significant as the (t) value is (5.600) with a degree of freedom (42) and a probability value (.000) agreement which means that objective types of questions do not assess all learning outcomes according to instructors' responses with $(0.05)$ of validity.

TABLE 7.

STUDENTS' INTERACTION

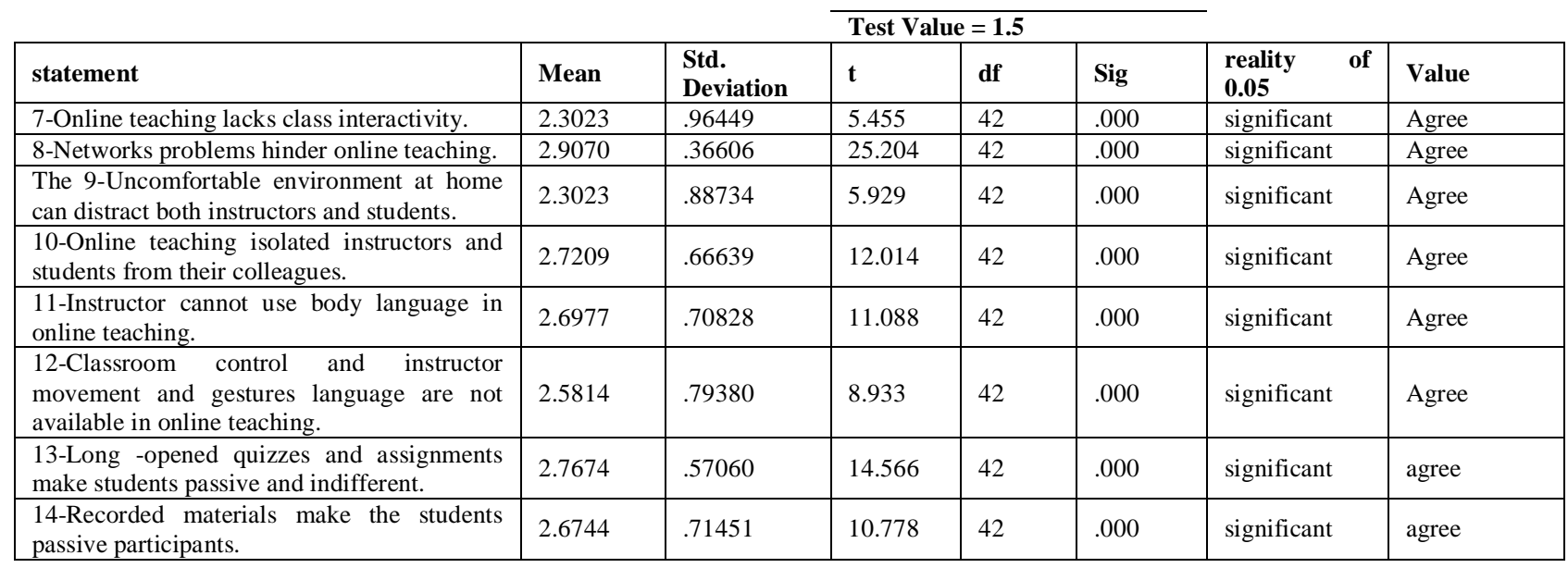

Seeing the of phrase No.7 in Table 7, results reveal that this phrase is significant as (t) value (5.455) with a degree of freedom (42) and a probability value (.000) agreement, which means online teaching lacks class interactivity according to instructors' responses with (0.05) of validity.

Seeing the of phrase No. 8 in Table 7, results reveal that this phrase is significant as (t) value (25.204) with a degree of freedom (42) and a probability value (.000) agreement, which means networks problems hinders online teaching according to instructors' responses with $(0.05)$ of validity. 
Seeing the of phrase No.9 in Table 7, results reveal that this phrase is significant as (t) value (5.929) with a degree of freedom (42) and a probability value (.000) agreement, which means uncomfortable environment at home can distract both instructors and students according to instructors' responses with $(0.05)$ of validity.

Seeing the of phrase No.10 in Table 7, results according to instructors' responses with (0.05) of validity, reveal that this phrase is significant as (t) value (12.014) with a degree of freedom (42) and a probability value (.000) agreement, which means online teaching isolated instructors and students from their colleagues.

Seeing the of phrase No. 11 in Table 7, results according to instructors' responses with (0.05) of validity reveal that this phrase is significant as (t) value (11.088) with a degree of freedom (42) and a probability value (.000) agreement, which means instructor cannot use body language in online teaching.

Seeing the of phrase No. 12 in Table 7, results according to instructors' responses with (0.05) of validity reveal that this phrase is significant as (t) value (8.933) with a degree of freedom (42) and a probability value (.000) agreement, which means classroom control and instructor movement and gestures language are not available in online teaching.

Seeing the of phrase No. 13 in Table 7, results according to instructors' responses with (0.05) of validity reveal that this phrase is significant as (t) value (14.566) with a degree of freedom (42) and a probability value (.000) agreement, which means long -opened quizzes and assignments make students passive and indifferent.

Seeing the of phrase No. 14 in Table 7, results according to instructors' responses with (0.05) of validity reveal that this phrase is significant as (t) value (10.778) with a degree of freedom (42) and a probability value (.000) agreement, which means recorded materials make the students passive participants.

TABLE 8

AUTHENTIC RESULTS OF LEARNING OUTCOMES

\begin{tabular}{|c|c|c|c|c|c|c|c|}
\hline \multirow[b]{2}{*}{ statement } & \multicolumn{7}{|c|}{ Test Value $=1.5$} \\
\hline & Mean & $\begin{array}{l}\text { Std. } \\
\text { Deviation }\end{array}$ & $\mathbf{t}$ & df & Sig & reality of 0.05 & Value \\
\hline $\begin{array}{l}\text { 15.Grades and online teaching results do not } \\
\text { accurately reflect students' standards. }\end{array}$ & 2.5116 & .82728 & 8.019 & 42 & .000 & significant & Agree \\
\hline $\begin{array}{l}\text { 16.Google is the only source for the students } \\
\text { in online learning. (copy / paste) }\end{array}$ & 1.6977 & .91378 & 1.419 & 42 & .163 & insignificant & No idea \\
\hline $\begin{array}{l}\text { 17.In online teaching, assessment is not } \\
\text { reliable due to many factors. }\end{array}$ & 2.4419 & .82527 & 7.484 & 42 & .000 & significant & Agree \\
\hline $\begin{array}{l}\text { 18.Online teaching resulted in students' } \\
\text { rudeness due to anxiety and other reasons. }\end{array}$ & 2.0930 & .89480 & 4.346 & 42 & .000 & significant & No idea \\
\hline $\begin{array}{l}\text { 19.Most students do not benefit from the } \\
\text { feedback of their instructors. }\end{array}$ & 2.0465 & .97476 & 3.676 & 42 & .001 & significant & No idea \\
\hline $\begin{array}{l}\text { 20.Students' behavior, contribution, and } \\
\text { progress are difficult to monitor in online } \\
\text { teaching. }\end{array}$ & 2.5581 & .82527 & 8.408 & 42 & .000 & significant & Agree \\
\hline $\begin{array}{l}\text { 21. When using online teaching, you cannot } \\
\text { keep students engaged in learning. }\end{array}$ & 2.0465 & .97476 & 3.676 & 42 & .001 & significant & No idea \\
\hline $\begin{array}{l}\text { 22.A large number of students in online } \\
\text { teaching negatively affects the learning } \\
\text { outcomes. }\end{array}$ & 2.3488 & .86969 & 6.400 & 42 & .000 & significant & Agree \\
\hline $\begin{array}{l}\text { 23.Online teaching resulted in a discrepancy } \\
\text { between the students' repeated absence and } \\
\text { their grades. }\end{array}$ & 2.6279 & .69087 & 10.706 & 42 & .000 & significant & Agree \\
\hline $\begin{array}{l}\text { 24.Online teaching makes students always } \\
\text { demand giving high marks. }\end{array}$ & 2.6279 & .75666 & 9.775 & 42 & .000 & significant & agree \\
\hline
\end{tabular}

Seeing the of phrase No. 15 in Table 8, results reveal that this phrase is significant as (t) value (8.019) with a degree of freedom (42) and a probability value (.000) agreement, which means "grades and results of online teaching do not accurately reflect students' standard according to instructors' responses with (0.05) of validity.

Seeing the of phrase No. 16 in Table 8, results reveal that this phrase is insignificant as (t) value (1.419) with a degree of freedom (42) and a probability value (.163) no idea, which means "Instructors did not agree and are not sure if Google is the only source for the students in online learning. (copy/paste)", with (0.05) of validity."

Seeing the phrase No. 17 in Table 8, results reveal that this phrase is significant as (t) value (7.484) with a degree of freedom (42) and a probability value (.000) agreement, which according to instructors' responses, means "In online teaching, assessment is not reliable due to many factors." with $(0.05)$ of validity.

Seeing the phrase No. 18 in Table 8, results reveal that this phrase is significant as (t) value (4.346) with a degree of freedom (42) and a probability value (.000) no idea, which means: "instructors are not sure if online teaching resulted in students' rudeness due to anxiety and other reasons or not." with (0.05) of validity.

Seeing the phrase No. 19 in Table 8, results reveal that this phrase is significant as (t) value (3.676) with a degree of freedom (42) and a probability value (.001) no idea, which means:" instructors are not sure if most students benefit from the feedback of their instructors or not" $(0.05)$ of validity.

Seeing the phrase No. 20 in Table 8, results reveal that this phrase is significant as (t) value (8.408) with a degree of freedom (42) and a probability value (.000) agreement, which means according to instructors' responses "students' behavior, contribution and progress are difficult to monitor in online teaching" with (0.05) of validity. 
Seeing the phrase No. (21) in Table 8, results reveal that this phrase is significant as (t) value (3.676) with a degree of freedom (42) and a probability value (.001) no idea, which according to instructors' responses with (0.05) of validity means "instructors are not sure about keeping students engaged in learning when using online teaching."

Seeing the of phrase No. (22) in Table 8, results reveal that this phrase is significant as (t) value (6.400) with a degree of freedom (42) and a probability value (.000) agreement, which according to instructors' responses means:" a large number of students in online teaching negatively affects the learning outcomes" with (0.05) of validity.

Seeing the of phrase No. (23) in Table 8, results reveal that this phrase is significant as (t) value (10.706) with a degree of freedom (42) and a probability value (.000) agreement, which according to instructors' responses means: "Online teaching resulted in a discrepancy between the students' repeated absence and their grades." with (0.05) of validity.

Seeing the of phrase No. (24) in Table 8, results reveal that this phrase is significant as (t) value (9.775) with a degree of freedom (42) and a probability value (.000) agreement, which according to instructors' responses means: "online teaching makes students always demand giving high marks" with $(0.05)$ of validity.

TABLE 9

INSTRUCTORS’ PLANNING AND CORRECTION LOAD

\begin{tabular}{|c|c|c|c|c|c|c|c|}
\hline \multicolumn{8}{|c|}{ Test Value $=1.5$} \\
\hline statement & Mean & $\begin{array}{l}\text { Std. } \\
\text { Deviation }\end{array}$ & $\mathbf{t}$ & df & Sig & reality of 0.05 & Value \\
\hline $\begin{array}{l}\text { 25.Online teaching demands multi-tasking } \\
\text { works for planning lessons which is } \\
\text { exhausting. }\end{array}$ & 2.4651 & .82661 & 7.656 & 42 & .000 & significant & Agree \\
\hline $\begin{array}{l}\text { 26.Online teaching is distressing to normal } \\
\text { life due to the numberless working hours. }\end{array}$ & 2.4651 & .82661 & 7.656 & 42 & .000 & significant & Agree \\
\hline $\begin{array}{l}\text { 27.Students' excuses for missing } \\
\text { assignments and quizzes makes more work } \\
\text { for the instructors. }\end{array}$ & 2.8605 & .51554 & 17.305 & 42 & .000 & significant & Agree \\
\hline 28.Online teaching is time-consuming. & 2.3953 & .90342 & 6.499 & 42 & .000 & significant & Agree \\
\hline $\begin{array}{l}\text { 29.Access to online materials is not always } \\
\text { possible. }\end{array}$ & 2.1163 & .98099 & 4.120 & 42 & .000 & significant & No idea \\
\hline $\begin{array}{l}\text { 30.Response to the repeated and different } \\
\text { students' contact adds another burden to } \\
\text { instructors. }\end{array}$ & 2.5116 & .76756 & 8.643 & 42 & .000 & significant & Agree \\
\hline $\begin{array}{l}\text { 31.Students do not commit to the deadline } \\
\text { of assignment questions. }\end{array}$ & 2.4884 & .85557 & 7.575 & 42 & .000 & significant & agree \\
\hline
\end{tabular}

Seeing the of phrase No. 25 in Table 9, results reveal that this phrase is significant as (t) value (7.656) with a degree of freedom (42) and a probability value (.000) agreement, which means according to instructors' responses with (0.05) of validity: "Online teaching demands multi-tasking works for planning lessons which is exhausting."

Seeing the of phrase No. 26 in Table 9, results reveal that this phrase is significant as (t) value (7.656) with a degree of freedom (42) and a probability value (.000) agreement, which means according to instructors' responses with (0.05) of validity: "Online teaching is distressing to normal life due to the numberless of working hours."

Seeing the of phrase No. 27 in Table 9, results reveal that this phrase is significant as (t) value (17.305) with a degree of freedom (42) and a probability value (.000) agreement, which means according to instructors' responses with (0.05) of validity: "Students' excuses for missing assignments and quizzes does more work for the instructors."

Seeing the of phrase No. 28 in Table 9, results reveal that this phrase is significant as (t) value (6.499) with a degree of freedom (42) and a probability value (.000) agreement, which means according to instructors' responses with (0.05) of validity: "Online teaching is time consuming."

Seeing the phrase No. 29 in Table 9, results reveal that this phrase is significant as (t) value (4.120) with a degree of freedom (42) and a probability value (.000) with (0.05) of validity, no idea, which means: "Instructors are not sure about the possibility of access to online materials."

Seeing the of phrase No. 30 in Table 9, results reveal that this phrase is significant as (t) value (8.643) with a degree of freedom (42) and a probability value (.000) agreement, which means according to instructors' responses with (0.05) of validity: "Response to the repeated and different contact from students add another burden to instructors.".

Seeing the of phrase No. 31 in Table 9, results reveal that this phrase is significant as (t) value (7.575) with a degree of freedom (42) and a probability value (.000) agreement, which means according to instructors' responses with (0.05) of validity: "Students do not commit to the deadline of assignment questions." 
TABLE 10

MACRO AND MICRO SKILLS

\begin{tabular}{|c|c|c|c|c|c|c|c|}
\hline \multirow[b]{2}{*}{ statement } & \multicolumn{6}{|c|}{ Test Value $=1.5$} & \multirow[b]{2}{*}{ Value } \\
\hline & Mean & $\begin{array}{l}\text { Std. } \\
\text { Deviation }\end{array}$ & $\mathbf{T}$ & df & Sig & reality of 0.05 & \\
\hline $\begin{array}{l}\text { 32.Due to students' invisibility, instructors } \\
\text { cannot accurately assess micro-speaking } \\
\text { skills. }\end{array}$ & 2.5349 & .82661 & 8.210 & 42 & .000 & significant & Agree \\
\hline $\begin{array}{l}\text { 33. Students' motivation is difficult to } \\
\text { evaluate in online teaching. }\end{array}$ & 2.5581 & .79589 & 8.718 & 42 & .000 & significant & Agree \\
\hline $\begin{array}{l}\text { 34.Listening skill is difficult to evaluate in } \\
\text { online teaching. }\end{array}$ & 2.0465 & .95002 & 3.772 & 42 & .001 & significant & No idea \\
\hline $\begin{array}{l}\text { 35.Writing skill is difficult to teach in } \\
\text { online teaching. }\end{array}$ & 2.4186 & .87919 & 6.851 & 42 & .000 & significant & Agree \\
\hline $\begin{array}{l}\text { 36. Micro skills are better to be taught in a } \\
\text { traditional classroom. (face to face). }\end{array}$ & 2.6279 & .72451 & 10.209 & 42 & .000 & significant & Agree \\
\hline $\begin{array}{l}\text { 37. Online teaching automatically makes } \\
\text { you less visible, which impacts your } \\
\text { authority. }\end{array}$ & 2.4651 & .85493 & 7.403 & 42 & .000 & significant & Agree \\
\hline
\end{tabular}

Seeing the of phrase No. 32 in Table 10, results reveal that this phrase is significant as (t) value (8.210) with a degree of freedom (42) and a probability value (.000) agreement, which means: "Due to students' invisibility instructor cannot accurately assess micro speaking skill." according to instructors' responses with $(0.05)$ of validity.

Seeing the of phrase No. 33 in Table 10, results reveal that this phrase is significant as (t) value (8.718) with a degree of freedom (42) and a probability value (.000) agreement, which means according to instructors' responses with (0.05) of validity: "Students motivation is difficult to evaluate in online teaching."

Seeing the phrase No. 34 in Table 10, results reveal that this phrase is significant as (t) value (3.772) with a degree of freedom (42) and a probability value (.000) with (0.05) of validity, no idea, which means: "Instructors are not sure about the difficulties of evaluating listening skill in online teaching."

Seeing the of phrase No. 35 in Table 10, results reveal that this phrase is significant as (t) value (6.851) with a degree of freedom (42) and a probability value (.000) agreement, which means according to instructors' responses with (0.05) of validity: "Writing skill is difficult to teach in online teaching."

Seeing the of phrase No. 36 in Table 10, results reveal that this phrase is significant as (t) value (10.209) with a degree of freedom (42) and a probability value (.000) agreement, which means according to instructors' responses with $(0.05)$ of validity: "Micro skills are better to be taught in a traditional classroom. (face to face)."

Seeing the of phrase No. 37 in Table 10, results reveal that this phrase is significant as (t) value (7.403) with a degree of freedom (42) and a probability value (.000) agreement, which means according to instructors' responses with (0.05) of validity: "Students do not commit to the deadline of assignment questions."

Most of the instructors 'answers of question No. 38 suggested blended learning, and asked for activating only one attempt in exams and quizzes to decrease cheating chance between students, and to reflect desired learning outcomes.

\section{RESULTS AND DisCUSSION}

\section{Quality of teaching, results' discussion:}

Findings showed that Online teaching does not achieve the prescribed learning outcomes as the students are passive in attending the lectures and only watch the recorded lectures and that agreed with Butcher and Hoosen (2014) study finding also showed that cheating on an online examination is inevitable and giving the students more than one attempt for the exam increases their chance of cheating, this agrees with Raines, et al. (2011) and Seife Dendirand, R. Stockton Maxwell (2020) and Ross, J. (2020) results, cheating can be solved if instructors consider Golden, J. and Kohlbeck, M. (2020) results, this beside students' repeated excuses and chances may reflect unreliable grades and results. These results are supported by Nauman A. and Munawar M. (2020). Also, results showed that most of the blackboard questions are objective, which does not assess all learning outcomes. These results limit the effectiveness of applying some of the online teaching principles that @ONE ONLINE NETWORK OF EDUCATORS mentions.

\section{Students' interaction, results' discussion:}

Finding of this domain showed that online teaching lacks class interactivity, as students do not normally use the microphone and depend on writing on the chatbox, also result showed how an Uncomfortable environment at home could distract both instructors and students not like being in a lecture room that is extremely prepared for learning purpose. Considering students and instructors meeting online participate in their isolation, losing contact by body language as students are reluctant to open the cameras, these finding are supported by Fageeh and Mekheimer (2013). Add to that online learning deprived instructors of using movement and gesture for illustration and depend only on intonation. This agrees with Al-Nofaie, H. (2020) and Leontyeva A. Irina (2018). Recorded materials, long-opened quizzes, and assignments make students passive participants and indifferent.

Authentic results of learning outcomes, results' discussion: 
This domain's finding showed that grades and results of online teaching do not accurately reflect students' standard and learning outcomes as mainly students tend to (copy/paste) from the internet websites, making assessment unreliable due to many factors. This agreed with Everett D. et al. (2015) and Pedersen C., White R. and Smith D. (2012) studies, add to that students' rudeness due to anxiety as Arnold S. (2012) mentioned. Results also showed that students don't benefit from their instructors' feedback. Results also showed students' behavior, contribution, and progress are difficult to monitor in online teaching because of students' large numbers, affecting their engagement. Result also revealed the discrepancy between the students' repeated absence and their grades and their demands for higher marks.

Instructors' planning and correction load results' discussion:

Finding of this domain showed that online teaching demands multi-tasking works for planning lessons which are exhausting and distressing to normal life due to the resultset of working hours and time-consuming these results are supported by Vadivel, B., Mathuranjali, M., and Khalil, N. R. (2021) Xhaferi, B., Tomei, L. A. (2006), and Xhaferi, G. (2020), and it is difficult for them to apply the 10 rules provided by Devenyi, G. A., et al. (2018).

Macro and Micro skills results' discussion:

This domain's finding showed that students' motivation is difficult on online teaching, and students do not always commit to the deadline of assignment questions, which is another burden to instructors for making makeup tests. This agrees with Narayanan, R., and Mathew, P. (2020) and Newman, B. (2020).

Due to students' invisibility, the instructor cannot accurately assess micro speaking and listening skills in online teaching; this agreed with Syahrin, S., and Salih, A. A. (2020) about productive skills speaking and writing, add to that the difficulties associated with teaching and evaluating writing and reading skills although these results agree with Newman, B. (2020). However, disagree with Haidari, M. et, al. (2020), Sherine, A . et, al. (2020) and Martínez, R., and Ruiz-Jiménez, M. (2020).

\section{CONCLUSION}

As a conclusion of this study, finding which are in divided into 5 domains, revealed the following:

A. Quality of teaching:

Online teaching does not achieve the prescribed learning outcomes because of students' cheating on online examinations, having more than one attempt and type of questions mostly objective questions.

B. Students' interaction

Online teaching lacks class interactivity due to network problems, distraction at home, students and isolation, and lack of class control and body language.

C. Authentic results of learning outcomes

Grades and online teaching results do not accurately reflect students' standards due to many factors such as cheating, many students, difficulties of monitoring students, and students' absence.

D. Planning and correction load:

Online teaching demands instructors multi-tasking works for planning lessons that are exhausting, time-consuming, and distressing to normal life. Add to that the burden of responding to the repeated questions to different students individually besides the students' unresponsiveness to dead time of activities.

E. Macro and Micro skills:

In online teaching, students' invisibility instructors cannot accurately assess micro and macro skills, speaking and reading skills in specific. Students' motivation is difficult to evaluate, while online teaching affects instructors' authority compared to traditional classrooms.

\section{APPENDIX. The QuestionnAIRE}

In the Name of Allah, the Merciful, the Compassionate

This questionnaire is designed to investigate the Challenges of Online English Teaching from EFL Instructors 'Point of View in KKU, Tehama Campus

\section{Part One Preface}

Dear instructors,

As a part of a research project on investigating "the Challenges of Online English Teaching", we would be grateful if you kindly, complete this questionnaire about the challenges you encounter when you practice teaching English online. The questionnaire describes different kinds of challenges suggested by scholars in this field. It is divided to 6 parts: basic information, quality of teaching, Students' interaction, Authentic results of learning comes, Instructors' planning and correction load and macro and micro skills.

Circle one of the options (Agree, Disagree, No idea). If you want to add anything else, please write it down on the lines provided.

\section{Part Two: Basic information}

1- Age: 25 and less than 35

45 and less than 55

2- Gender 35and less than 45

55 and less than 65 
Male $\square \quad$ Female $\square$

3- I have you been teaching in KKU for

$1-5$ years $\square \quad 6-10$ years $\square$

11-15 years $\square \quad$ More than 15 years

4- I experienced E- teaching before Covid19.

Yes $\square \quad$ No $\square$

Part three: Questions:

A. Quality of teaching:

\begin{tabular}{|l|l|l|l|}
\hline No. & Statement & Agree & Disagree \\
\hline $\mathbf{1}$ & Online teaching does not achieve the prescribed learning outcomes. & & \\
\hline $\mathbf{2}$ & Cheating on online examination is inevitable. & & \\
\hline $\mathbf{3}$ & $\begin{array}{l}\text { Having more than one attempt for the exam increases the students' chance of } \\
\text { cheating. }\end{array}$ & & \\
\hline $\mathbf{4}$ & $\begin{array}{l}\text { Students repeated excuses and chances may reflect unreliable grades and } \\
\text { results. }\end{array}$ & & \\
\hline $\mathbf{5}$ & Most of blackboard questions are objective. & & \\
\hline $\mathbf{6}$ & Objective types of questions do not assess all learning out comes. & & \\
\hline
\end{tabular}

\section{B. Students' interaction:}

\begin{tabular}{|l|l|l|l|}
\hline $\mathbf{N o}$ & Statement & Agree & Disagree \\
\hline $\mathbf{7}$ & Online teaching lacks class interactivity. & & \\
\hline $\mathbf{8}$ & Networks problems hinders online teaching. & & \\
\hline $\mathbf{9}$ & $\begin{array}{l}\text { Uncomfortable environment at home can distract both instructors and } \\
\text { students. }\end{array}$ & & \\
\hline $\mathbf{1 0}$ & Online teaching isolated instructors and students from their colleagues. & & \\
\hline $\mathbf{1 1}$ & Instructor cannot use body language in online teaching. & & \\
\hline $\mathbf{1 2}$ & $\begin{array}{l}\text { Classroom control and instructor movement and gestures language are not } \\
\text { available in online teaching. }\end{array}$ & & \\
\hline $\mathbf{1 3}$ & $\begin{array}{l}\text { Long -opened quizzes and assignments make students passive and } \\
\text { indifferent. }\end{array}$ & & \\
\hline $\mathbf{1 4}$ & Recorded materials make the students passive participants. & & \\
\hline
\end{tabular}

\section{Authentic results of learning outcomes:}

\begin{tabular}{|c|c|c|c|c|}
\hline No. & Statement & Agree & Disagree & No idea \\
\hline 15 & $\begin{array}{l}\text { Grades and results of online teaching do not accurately reflect students' } \\
\text { standard. }\end{array}$ & & & \\
\hline 16 & Google is the only source for the students in online learning. (copy / paste) & & & \\
\hline 17 & In online teaching assessment is not reliable due to many factors. & & & \\
\hline 18 & $\begin{array}{l}\text { Online teaching resulted in students' rudeness due to anxiety and other } \\
\text { reasons. }\end{array}$ & & & \\
\hline 19 & Most students do not benefit from the feedback of their instructors. & & & \\
\hline 20 & $\begin{array}{l}\text { Students' behavior, contribution and progress are difficult to monitor in } \\
\text { online teaching. }\end{array}$ & & & \\
\hline 21 & When using online teaching you cannot keep students engaged in learning. & & & \\
\hline 22 & $\begin{array}{l}\text { A large number of students in online teaching negatively affects the learning } \\
\text { outcomes. }\end{array}$ & & & \\
\hline 23 & $\begin{array}{l}\text { Online teaching resulted in a discrepancy between the students' repeated } \\
\text { absence and their grades. }\end{array}$ & & & \\
\hline 24 & Online teaching makes students always demand giving high marks. & & & \\
\hline
\end{tabular}

\section{Instructors' planning and correction load:}

\begin{tabular}{|l|l|l|l|}
\hline No. & Statement & Agree & Disagree \\
\hline $\mathbf{2 5}$ & $\begin{array}{l}\text { Online teaching demands multi-tasking works for planning lessons which } \\
\text { is exhausting. }\end{array}$ & & No idea \\
\hline $\mathbf{2 6}$ & $\begin{array}{l}\text { Online teaching is distressing to normal life due to the numberless of } \\
\text { working hours. }\end{array}$ & & \\
\hline $\mathbf{2 7}$ & $\begin{array}{l}\text { Students' excuses for missing assignments and quizzes makes more work } \\
\text { for the instructors. }\end{array}$ & & \\
\hline $\mathbf{2 8}$ & Online teaching is time consuming. & & \\
\hline $\mathbf{2 9}$ & Access to online materials is not always possible. & & \\
\hline $\mathbf{3 0}$ & $\begin{array}{l}\text { Response to the repeated and different contact from students adds another } \\
\text { burden to instructors. }\end{array}$ & & \\
\hline $\mathbf{3 1}$ & Students do not commit to the deadline of assignment questions. & & \\
\hline
\end{tabular}

\section{E. Macro and Micro skills:}




\begin{tabular}{|l|l|l|l|l|}
\hline No. & Statement & Agree & Disagree & No idea \\
\hline $\mathbf{3 2}$ & $\begin{array}{l}\text { Due to students' invisibility instructor cannot accurately assess micro } \\
\text { speaking skills. }\end{array}$ & & & \\
\hline $\mathbf{3 3}$ & Students motivation is difficult to evaluate in online teaching. & & & \\
\hline $\mathbf{3 4}$ & Listening skill is difficult to evaluate in online teaching. & & & \\
\hline $\mathbf{3 5}$ & Writing skill is difficult to teach in online teaching. & & & \\
\hline $\mathbf{3 6}$ & Micro skills are better to be taught in a traditional classroom. (face to face). & & & \\
\hline $\mathbf{3 7}$ & $\begin{array}{l}\text { Online teaching automatically makes you less visible, which impacts your } \\
\text { authority. }\end{array}$ & & & \\
\hline
\end{tabular}

S38. Anything to add.

\section{REFERENCES}

[1] @ONE ONLINE NETWORK OF EDUCATORS, Principles for Quality Online Teaching, retrieved on January, 10, 2021 from https://onlinenetworkofeducators.org/course-cards/principles-quality-online-teaching/.

[2] A Guide to Quality in Online Learning retrieved on January, 10, 2021 from https://www.tonybates.ca/wpcontent/uploads/Guide_Quality_Online.pdf.

[3] Abuhammad S. (2020) Barriers to distance learning during the COVID-19 outbreak: A qualitative review from parents' perspective. Heliyon, 6 (2020) e05482 retrieved on January, 10, 2021 from https://doi.org/10.1016/j.heliyon.2020.e05482.

[4] Adedoyin O. B.Soykan E. (2020). Covid-19 pandemic and online learning: the challenges and opportunities. Interactive Learning Environment, retrieved on January, 10, 2021 from https://doi: 10.1080/10494820.2020.1813180.

[5] Al-Nofaie, H. (2020). Saudi University Students' Perceptions towards Virtual Education During Covid-19 Pandemic: A Case Study of Language Learning via Blackboard. Arab World English Journal, 11 (3) 4-20. retrieved on January, 10, 2021 DOI: https://dx.doi.org/10.24093/awej/vol11no3.1.

[6] Arnold S. D. (2012) Assessing Student Learning Online: Overcoming Reliability Issues. IADIS International Conference on Cognition and Exploratory Learning in Digital Age, CELDA retrieved on January 10, 2021 https://files.eric.ed.gov/fulltext/ED542719.pdf.

[7] ARMĂSAR, I. P. (2020). Challenges of Online Teaching in the Business Language Class. Bulletin of the Transilvania University of Brasov. Series V: Economic Sciences, 13(2), 149-156 retrieved on January 10, 2021. https://doiorg.sdl.idm.oclc.org/10.31926/but.es.2020.13.62.2.16.

[8] Azubuike O. B. Adegboye O. Quadri H. (2020). Who gets to learn in a pandemic? Exploring the digital divide in remote learning during the COVID-19 pandemic in Nigeria, International Journal of Educational Research Open 2(2 156 retrieved on January, 10, 2021)_https://doi.org/10.1016/j.ijedro.2020.100022.

[9] Bunmi S. Malau-Aduli, Dwight Assenheimer, Derek Choi-Lundberg and Craig Zimitat. (2014). Using computer-based technology to improve feedback to staff and students on MCQ assessments, Innovations in Education and Teaching International, 51 (5 ) p. 510-522 retrieved on January, 10, 2021 from https://doi.org/10.1080/14703297.2013.796711.

[10] Butcher, N. and Wilson-Strydom, M. (2013). A Guide to Quality in Online Learning Dallas TX: Academic Partnerships retrieved on January, 10, 2020 from: https://www.tonybates.ca/wp-content/uploads/Guide_Quality_Online.pdf.

[11] Butcher, N. and Hoosen, S. (2014). A Guide to Quality in Post-traditional Online Higher Education Dallas TX: Academic Partnerships, retrieved on January, 10, 2021 from: https://www.tonybates.ca/wpcontent/uploads/Guide_Quality_Online_LearningBooklet_V4_final.pdf.

[12] Christine Frazer, Debra Henline Sullivan, Deborah Weatherspoon, Leslie Hussey. (2017). "Faculty Perceptions of Online Teaching Effectiveness and Indicators of Quality", Nursing Research and Practice, vol. 2017, Article ID 9374189, 6 pages, retrieved on January, 10, 2021 from https://doi.org/10.1155/2017/9374189.

[13] Chung, Ellen, Subramaniam, Geetha and Dass, Laura Christ. Online learning readiness among university students in Malaysia amidst Covid-19. Asian Journal of University Education ,16 (2) p46-58 retrieved on January, 10, 2021 from https://doi.org/10.24191/ajue.v16i2.10294.

[14] Devenyi, G. A., Emonet, R., Harris, R. M., Hertweck, K. L., Irving, D., Milligan, I., and Wilson, G. (2018). Ten simple rules for collaborative lesson development. PLoS Computational Biology, 14(3), 1-8 retrieved on January, 10, 2021 from. https://doi-org.sdl.idm.oclc.org/10.1371/journal.pcbi.1005963.

[15] Everett D. R,. Adding Value: Online Student Engagement. Proceedings of the Information, Systems Educators Conference, ISECON 2014.

[16] Fageeh, A., and Mekheimer, M. (2013). Effects of BlackBoard on EFL academic writing and attitudes. JALT CALL Journal, 9(2), 169-196. retrieved on January, 10, 2021 from https://doi: 10.29140/jaltcall.v9n2.154.

[17] Golden, J. and Kohlbeck, M. (2020). Addressing cheating when using test bank questions in online Classes, Journal of Accounting Education, v 52 retrieved on January, 10, 2021 from https://doi.org/10.1016/j.jaccedu.2020.100671.

[18] Haidari, M., Katawazai, R., and Yusof, S. M. (2020). The Use of Social Media and Wikis in Teaching Writing Skills: A Review Article. International Journal of Interactive Mobile Technologies, 14(16), 168-179. retrieved on January, 10, 2021 from https://doi-org.sdl.idm.oclc.org/10.3991/ijim.v14i16.15531.

[19] Hee K. (2013). Factors of learner-instructor interaction which predict perceived learning outcomes in online learning environment. Journal of Computer Assisted Learning (2013), 29, 292-301.

[20] Kang M.Im T.(2013). Factors of learner-instructor interaction which predict perceived learning outcomes in online learning environment., Journal of Computer Assisted Learning 3(29),291-301 retrieved on January, 10, 2021 from https://doi.org/10.1111/jcal.12005. 
[21] Kiili, C., and Leu, D. J. (2019). Exploring the collaborative synthesis of information during online reading. in Human Behavior, 95, 146-157. retrieved on January, 10, 2021 from https://doi-org.sdl.idm.oclc.org/10.1016/j.chb.2019.01.033.

[22] Lathifah Z, Helmanto F, Maryani, N. (2020). The practice of effective classroom management in COVID-19 time, International Journal Of Advance Science and Technology, 29 (7) 3263-3271. retrieved on January 10, 2021 from http://sersc.org/journals/index.php/IJAST/article/view/18955.

[23] Leontyeva A. Irina. (2018). Modern Distance Learning Technologies in Higher Education: Introduction Problems, URASIA Journal of Mathematics, Science and Technology Education,14(10) retrieved on January 10,2021 from https://www.ejmste.com/download/modern-distance-learning-technologies-in-higher-education-introduction-problems5542.pdf.

[24] Martínez-Jiménez, R., and Ruiz-Jiménez, M. C. (2020). Improving students' satisfaction and learning performance using flipped classroom. The International Journal of Management Education, 18(3). retrieved on January 10,2021 from https://doiorg.sdl.idm.oclc.org/10.1016/j.ijme.2020.100422.

[25] Nauman A. Ahmed, Munawar M. Sultana. (2020). Evaluating Pre-Service Teaching Practice for Online and Distance Education Students in Pakistan, International Review of Research in Open and Distributed Learning,21(2) p. 91-98 retrieved on January, 10, 2021 from : https://doi.org/10.19173/irrodl.v21i2.4606.

[26] Narayanan, R., and Mathew, P. (2020). Teaching International English Language Testing System (IELTS) Academic Writing and Exam Strategies Online to Develop Omani Students' Writing Proficiency. Arab World English Journal, (AWEJ) Proceedings of 2nd MEC TESOL Conference 22020 49-63. retrieved on January, 10, 2021 from https://doiorg.sdl.idm.oclc.org/10.24093/awej/MEC2.4.

[27] NEWMAN, B. M. (2020). When the Classroom Becomes a Screen: Finding Our Talent Zones for Teaching. English Journal, $110(2), 55-61$

[28] Nguyen, Khang D., et al. (2020). Opportunities for education during the COVID-19 pandemic, JAAD International, retrieved on January, 10, 2021 from: https://doi.org/10.1016/j.jdin.2020.04.003.

[29] Pedersen C.White R.Smith D. (2012). International Journal of Organisational Behaviour 17(3) 33-45

[30] Reese, S. A. (2014). Online learning environments in higher education: Connectivism vs. dissociation. Education and Information Technologies, 20(3), 579-588. retrieved on January, 10, 2021 from https://Doi:10.1007/s10639-013-9303-7.

[31] Ross, J. (2020). Crisis-driven online exam shift 'chance to boost academic integrity. Times higher education, retrieved on January, 10, 2021 from: https://www.timeshighereducation.com/news/crisisdriven-online-exam-shift-chance-boost-academicintegrity.

[32] Raines, et.al (2011). Cheating In Online Courses: The Student Definition, The Journal of Effective Teaching, 11(1) 80-89, retrieved on January, 10, 2021 from https://files.eric.ed.gov/fulltext/EJ1092169.pdf.

[33] Seife Dendirand, R. Stockton Maxwell. (2020). Cheating in online courses: Evidence from online proctoring, Computers in Human Behavior Reports journal, v.2, retrieved on January, 10, 2021 from https://doi.org/10.1016/j.chbr.2020.100033.

[34] Sherine, A., Sastry, M. M., and Seshagiri, A. V. S. (2020). Improving Second Language Speaking and Pronunciation Through Smartphones. International Journal of Interactive Mobile Technologies, 14(11), 280-287. retrieved on January, 10, 2021 fromhttps://doi-org.sdl.idm.oclc.org/10.3991/ijim.v14i11.13891.

[35] Srivastava, R. (2020). Unlocking Technology for Language Learning: A Viability at the Time of Transition from Traditional to Online Teaching and Learning. Arab World English Journal, 96-110. https://doi-org.sdl.idm.oclc.org/10.24093/awej/MEC2.7.

[36] Syahrin, S., and Salih, A. A. (2020). An ESL Online Classroom Experience in Oman during Covid-19. Arab World English Journal, 11(3), 42-55. retrieved on January, 10, 2021 from https://doi-org.sdl.idm.oclc.org/10.24093/awej/vol11no3.3.

[37] Tomei, L. A. (2006). The Impact of Online Teaching on Faculty Load: Computing the Ideal Class Size for Online Courses. Journal of Technology and Teacher Education, 14(3), 531-541. retrieved on January, 10, 2021 from http://search.ebscohost.com.sdl.idm.oclc.org/login.aspx?direct=true\&db=ehh\&AN=20208790\&site=eds-live.

[38] Vadivel, B., Mathuranjali, M., and Khalil, N. R. (2021). Online teaching: Insufficient application of technology. Materials Today: Proceedings. retrieved on January, 10, 2021 from https://doi-org.sdl.idm.oclc.org/10.1016/j.matpr.2021.01.454.

[39] Xhaferi, B., and Xhaferi, G. (2020). Online Learning Benefits and Challenges During the COVID 19 - Pandemic-Students' Perspective from SEEU. SEEU Review, 15(1), 86-103. retrieved on January, 10, 2021 from https://doiorg.sdl.idm.oclc.org/10.2478/seeur-2020-000.

Mona M. Hamad is a Sudanese, her Ph.D. in Education "Curriculum \& Teaching Methods of English Language" from AlZaiemAzhhri University, Khartoum, Sudan. She obtained her Master degree in Education Technology (2005) from Al-ZaiemAzhhri University, Khartoum, Sudan. She also obtained a higher degree Diploma in ELT (2001) from Khartoum University, Khartoum, Sudan. Her Bachelor of Arts (1991) was obtained from AL-Neelain University, Khartoum, Sudan.

She has been working as Assistant Professor at King Khalid University, Muhayil, English Department since 2012. She has worked as a part-time Assistant Professor for Al-ZaiemAzhhri University, Sudan, Khartoum from 2010-2012. She also worked as English language teacher for Secondary level for the Ministry of General Education, Sudan from 1996-2012. She published many papers and two books titled:

1. Revision papers for Secondary Students, Khartoum, Sudan

2. Special Teaching Methods, Khartoum, Al-ZaiemAzhhri University, Sudan.

Dr. Mona M. Hamad is a member of KSAALT /TESOL (Kingdom of Saudi Arabia Association of English Language Teachers) ASTEL (Association of Sudanese Teachers of English Language).

Alrafeea S. Dafaallah is a Sudanese, got his Ph.D. in Education "Strategies for Developing English oral Communication in Sudanese Secondary Schools" from Sudan University for Science \& Technology, Khartoum, Sudan. He obtained his Master degree 
in Education (1998) from Al-Jazeera University, Madani, Sudan. He also obtained a higher degree Diploma in ELT (1996) from Khartoum University, Khartoum, Sudan. His Bachelor of English Language \& Arts (1994) was obtained from Omdurman Islamic University, Omdurman, Sudan.

He has been working as Assistant Professor at King Khalid University, Muhayil, English Department since 2012. He also worked as English language lecturer for Aljouf University, K..S.A. Between 2005-2012. He published many papers.

1. Achievement Tests Influence on Developing Receptive Skills: (Case Study of Undergraduate Students at Science and Humanities College - Shaqra University - KSA)

2. Investigating Students Learning Strategies of Medical Vocabulary: Case Study of the Faculty of Medicine, Karari UniversitySudan.

Abdulbasit A. Alhaj is a Sudanese, his Ph.D. in Linguistics "Language Education Problems in the Context of Coflict" from Khartoum University, Khartoum, Sudan. He obtained his Master degree in English Language Teaching (ELT) (2004) from Khartoum University, Khartoum, Sudan. He also obtained a higher degree Diploma in ELT (2001) from Khartoum University, Khartoum, Sudan. His Bachelor of Education and Arts (1997) was obtained from AL-Fasher University, Al-Fasher, Sudan.

He has been working as Assistant Professor at King Khalid University, Muhayil, English Department since 2014. He has worked Assistant Professor for Nyla University, Sudan, Nyala from 2013-2014. He also worked as a lecturer at Nyala University from 2004 to 2009 . 